\title{
Antioxidant Activity and Cytotoxic Potential of Parijoto (Medinilla speciosa (Reinw ex BL)) Fruit Fractions on HeLa Cell Line
}

\author{
Aji Winanta*, Linta Sabila Hanik, Rifki Febriansah
}

Department of Pharmaceutical Biology, Faculty of Medicine and Health Sciences, Universitas Muhammadiyah Yogyakarta, Yogyakarta, Indonesia

\begin{abstract}
Parijoto (Medinilla speciosa (Reinw ex BL)) is one of the Indonesian indigenous plants widely used as traditional medicine. A previous study showed that ethanol and methanol extracts of Parijoto fruit could inhibit T47D breast cancer cells. This study explores the antioxidant and cytotoxic activities of Parijoto fruit extract and fractions on HeLa cell line. The fruits were extracted using ethanol $70 \%$ and fractionated by hexane and ethyl acetate. Furthermore, the fraction was analyzed for secondary phytochemical metabolite content using thin-layer chromatography and staining reagents. The antioxidant and cytotoxic activities were determined using the DPPH scavenging assay and the MTT assay, respectively. The ethanol extract and fraction contained flavonoid and tannin compounds. Ethanol extract, ethanol fraction, and ethyl acetate fraction of Parijoto fruit had an antioxidant activity with $\mathrm{IC}_{50}$ values of $77.3,88.64$, and $46.61 \mu \mathrm{g} / \mathrm{mL}$, respectively. Ethyl acetate fraction showed the highest activity on HeLa cells with an IC $\mathrm{I}_{50}$ value of $45.57 \mu \mathrm{g} / \mathrm{mL}$ compared to ethanol extract, ethanol fraction and $\mathrm{n}$-hexane fraction with an $\mathrm{IC}_{50}$ value of $233.43,700.75$, and $534.30 \mu \mathrm{g} /$ $\mathrm{mL}$, respectively. Based on these results, the ethyl acetate fraction of Parijoto fruit had the potency to be explored further to elucidate their cytotoxicity mechanism in HeLa cells.
\end{abstract}

Keywords: antioxidant activity, cytotoxicity, Medinilla speciosa, Parijoto fruit fractions.

\section{INTRODUCTION}

Cancer is the second leading cause of mortality in the world after heart disease and is responsible for 9.6 million deaths in 2018. Cervical cancer, cancer that causes the highest death rate, represents $6.6 \%$ of all cancers that attack women with 570,000 new cases and 311.00 deaths in 2018 (World Health Organization, 2018). Recently, various cancer therapies, such as chemotherapy, radiotherapy, and surgery, have been developed (Manuaba, 2010). The chemotherapy has a mechanism in inhibiting the cell as a whole, both cancer cells and normal cells. However, this treatment causes some side effects such as hepatotoxicity, cardiotoxicity, nausea and vomiting, diarrhea and anorexia (Huang, et al., 2017; Oun, et al., 2018). Therefore, the discovery of an effective and safe chemopreventive agent should be explored.

The discovery of natural and safe chemopreventive agents is still ongoing these days. For

Submitted: August 24, 2020

Revised: April 16, 2021

Accepted: April 29, 2021

*Corresponding author: ajiwinanta@umy.ac.id 
thousands of years, raw materials from plants have been used as medicine (Krueger, 2005). One widely used plant as medicine by some people in Indonesia is the 'Parijoto' fruit (Medinilla speciosa Reinw. ex. Bl). Parijoto fruit is one of the most widely cultivated plants in the Muria Mountains, Kudus Regency. People in there generally consume this fruit as mouth ulcer medication.

Phytochemical components in parijoto fruit include flavonoids, saponins, kardenolin, terpenoid and tannins (Ministry of Health RI, 2006; Vifta and Advistasari, 2018). These compounds could inhibit the cancer growth. Flavonoids have anticancer properties because they prevent cancer cell growth and tumour expansion (Ren, et al., 2003). Anti-tumor effects of saponins have been reported in several cancer cells (Man, et al., 2010; Yang, et al., 2018). A previous study conducted by Tussanti, et al. (2014) found that the parijoto methanol extract's has cytotoxic effect on breast cancer cells (T47D). In addition, parijoto fruit has a vigorous antioxidant activity (Wachidah, 2013). However, the cytotoxic activity of parijoto fruits on cervival cancer remains unclear. Therefore in this study we explored the cytotoxic activity of Parijoto fruits on HeLa cells.

In this study, a phytochemical test was carried out to ensure the presence of flavonoids and phenolic in Parijoto fruit fractions. Furthermore, the potential of antioxidant and cytotoxic activity against $\mathrm{HeLa}$ cervical cancer cells will also be examined in vitro. This study can be used as a scientific basis for empirical evidence of Parijoto to be developed as chemopreventive agent.

\section{MATERIALS AND METHODS}

\section{Materials}

Parijoto fruits were collected from Kudus, Central Java, Indonesia. The fruits were identified in the Faculty of Pharmacy UAD, Indonesia, under Nr.13/Lab.Bio/B/III/2020. Extraction and fractionation solvents used in this study were ethanol, hexane, and ethyl acetate (technical grade). Ma- terials used for phytochemical assay were acetyl acid (Merck, Darmstadt, Germany,), n-butanol (Merck); NH4OH, FeCl3 (Merck); HCl (Mallinckrodt, Blanchardstown Dublin, Ireland), Dregendrof reagent, $\mathrm{NaOH}$ (Merck), TLC silica gel GF254 (Merck), and rutin (Sigma-Aldrich, Germany). Materials used for antioxidant activity and cytotoxic assays were 2,2-diphenyl-1-picrylhydrazyl (DPPH), ascorbic acid (Merck), 3-(4,5-dimethylthiazol-2-yl)-2,5-diphenyltetrazolium bromide (MTT) (Bio basic, Canada) and sodium dodecyl sulfate (SDS) (Merck) as stopper reagent. The cervical cancer cell line (HeLa) was propagated using the following growth media: RPMI 1640 (Gibco, New York, USA).

\section{Extraction and Fractionation Procedures}

Approximately $375 \mathrm{mg}$ of dried parijoto fruit were firstly macerated with 1:6 of ethanol $70 \%$ for 5 days. Afterword, the recidue was then re-maserated for 3 days. The filtrate was evaporated using a rotary evaporator at $600 \mathrm{C}$ under vacuum to get a crude extract. Furthermore, the filtrate was fractioned using hexane and ethyl acetate in a ratio of 1:1 three times. The hexane containing extract were combined to produce a hexane fraction. The hexane insoluble residue was further partitioned with ethyl acetate to produce ethyl acetate fraction and ethanolic fraction and the fractions filtrate was evaporated undevreduced pressure to obtain the crude hexane, ethyl acetat and ethanol fraction (Phang, et al., 2013; Tusanti, et al., 2014).

\section{Phytochemistry Evaluation}

Preliminary qualitative phytochemical analysis was carried out to identify the secondary metabolite of parijoto fruit fraction such as flavonoid, alkaloids and tannin. Phytochemical analysis was analyzed using the TLC silica gel 60F254 plate with mobile phase, butanol: acetic acid: water $(3: 1: 1 \mathrm{v} / \mathrm{v} / \mathrm{v})$. The samples were determined under UV254 and UV366 lights before and after spraying with ammonia vapor to identify fla- 
vonoids (Jork, 1990). The reagent dragendrof and $\mathrm{FeCl} 3$ were used to identify alkaloids and tannin (Ayoola, et al., 2008; Tiwari, et al., 2011).

\section{2,2-diphenyl-1-picrylhydrazyl (DPPH) Radi- cal Scavenging Assay}

The DPPH radical scavenging activity was analyzed according to Kaulika and Febriansah (2019). Sample of ethanol extract, hexane fraction, ethyl acetate fraction, and the ethanolic fraction was diluted to final concentrations of $60,50,40$, 30 , and $20 \mu \mathrm{g} / \mathrm{mL}$ on methanol. One $\mathrm{mL}$ of a 0.4 $\mathrm{mM}$ DPPH methanol solution was added to give 5 $\mathrm{mL}$ of sample solutions of different concentrations and homogenized using a vortex, then incubated at room temperature for 30 minutes. Absorbance was analysed at $517 \mathrm{~nm}$ using a spectrophotometer. DPPH solution was used as a control, methanol was used as a blank, and vitamin C was used as a positive standard (Kaulika and Febriansah, 2019). The percentage of inhibition activity was calculated as $[(\mathrm{A} 0-\mathrm{A} 1) / \mathrm{A} 0] \times 100$, where $\mathrm{A} 0$ was the absorbance of the control, and A1 was the absorbance of the extract/standard. The absorbance value was pro- cessed into percentage antioxidant to perform $\mathrm{IC}_{50}$ calculations (Phang, et al., 2013).

\section{Cytotoxic Assay In Vitro}

The samples were diluted on DMSO and were added by serial concentrations (12.5-200 $\mu \mathrm{g} / \mathrm{mL}$ ). Doxorubicin (15.25-250 ppm) was used as a positive control, untreated cells were used as negative control, and medium control. The HeLa Cell lines were transferred onto micro titer-plate in $7.5 \times 10^{3}$ cells/well and incubated for $24 \mathrm{~h}$ in a $\mathrm{CO}_{2}$ incubator. Samples were added by serial dilution (12.5-200 ppm) then incubated for $24 \mathrm{~h}$ in a $\mathrm{CO}_{2}$ incubator. The medium was removed, then the MTT $5 \mathrm{mg} / \mathrm{mL}$ was put in PBS solution $100 \mu \mathrm{l} /$ well and incubated for 3-4 $\mathrm{h}$ in a $\mathrm{CO}_{2}$ incubator until formazan was formed. Furthermore, the $0.1 \%$ SDS was put in $0.01 \mathrm{~N} \mathrm{HCl}$ as a stopper and incubated for $24 \mathrm{~h}$. The viability cells were analysed by ELISA reader at $595 \mathrm{~nm}$. The absorption value was converted to $\%$ cell viability, and $\mathrm{IC}_{50}$ was calculated by the equation $\mathrm{y}=\mathrm{bx}+\mathrm{a}$ obtained from the linear regression between the concentration and \% cell viability (Riss, et al., 2013).

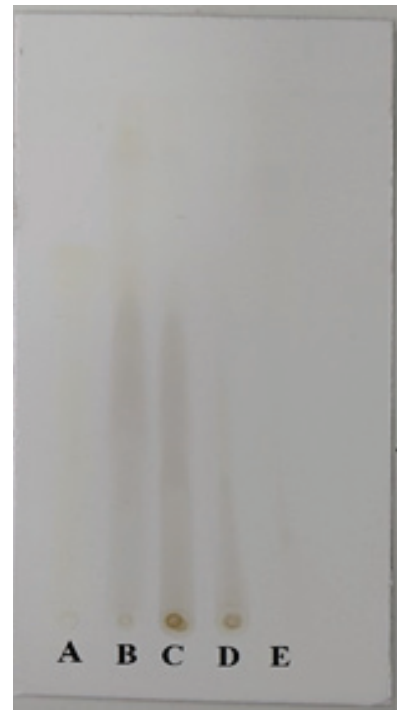

Visible light

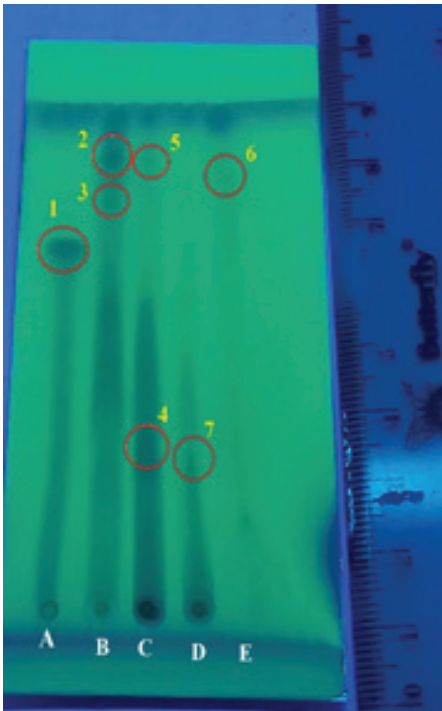

UV 254 nm

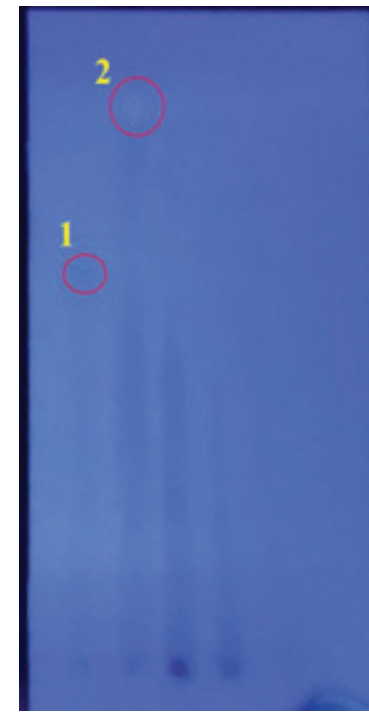

UV $366 \mathrm{~nm}$

Figure 1. TLC profile after ammonia vapourized. (A) Rutin standart (B) Ethyl acetate fraction (C) Ethanolic extract (D) Ethanolic fraction and (e) n-hexane fraction. TLC system: stationary phase silica gel F254, mobile phase butanol: astic acid: water (3:1:1 v/v/v). 
Indonesian Journal of Cancer Chemoprevention, June 2021

Table 1. TLC test's results of extract and fraction of Parijoto fruit.

\begin{tabular}{|c|c|c|c|c|c|}
\hline Sample & $\begin{array}{c}\text { Spot } \\
\text { Number }\end{array}$ & Rf value & $\begin{array}{l}\text { Visible } \\
\text { Light }\end{array}$ & UV 254 nm & UV $366 \mathrm{~nm}$ \\
\hline Routine & I & 0.83 & $\begin{array}{l}\text { Brownish- } \\
\text { yellow }\end{array}$ & Brown & Brown \\
\hline Ethyl Acetate Faction & $\begin{array}{l}2 \\
3\end{array}$ & $\begin{array}{l}0.92 \\
0.81\end{array}$ & $\begin{array}{l}\text { Brown } \\
\text { Brown }\end{array}$ & $\begin{array}{l}\text { Brown } \\
\text { Brown }\end{array}$ & $\begin{array}{l}\text { Fluorescent } \\
\text { bluish }\end{array}$ \\
\hline Ethanol Extract & $\begin{array}{l}4 \\
5\end{array}$ & $\begin{array}{l}0.31 \\
0.91\end{array}$ & $\begin{array}{c}\text { Brown } \\
-\end{array}$ & $\begin{array}{l}\text { Brown } \\
\text { Brown }\end{array}$ & - \\
\hline $\begin{array}{l}\text { Ethanol Fraction } \\
\mathrm{n} \text {-hexane fraction }\end{array}$ & $\begin{array}{l}7 \\
6\end{array}$ & $\begin{array}{l}0.30 \\
0.85\end{array}$ & $\begin{array}{c}\text { Brown } \\
-\end{array}$ & $\begin{array}{c}\text { Brown } \\
\text { Light brown }\end{array}$ & $\begin{array}{l}- \\
-\end{array}$ \\
\hline
\end{tabular}

\section{RESULTS}

\section{Phytochemical Analysis}

The yield of Parijoto's thick ethanol extract (Medinilla speciosa Reinw. ex. Bl) was $8.89 \% \mathrm{w} / \mathrm{w}$, and the yield of the ethanol, ethyl acetate, n-hexane fractions was $66 \% \mathrm{w} / \mathrm{w}, 28 \% \mathrm{w} / \mathrm{w}$, and $6 \% \mathrm{w} / \mathrm{w}$, respectively.

Based on the identification of compounds using TLC, ethanol extract, ethyl acetate, ethanol fraction \& n-hexane fraction were considered to contain flavonoids as there were brown spots after being steamed with ammonia in visible light, 254 nm UV light, and a bluish glow on $366 \mathrm{~nm}$ UV light (Harborne, 1987; Jork, 1990).

The results of phytochemical screening showed that the ethanol extract, ethyl acetate fraction, and ethanol fraction positively contained flavonoids and tannins. Meanwhile, Parijoto fruit extract and fraction negatively contained alkaloids.

\section{2,2-diphenyl-1-picrylhydrazyl (DPPH) Radi- cal Scavenging Assay}

The Parijoto fruit extract and fraction have antioxidant activity based on DPPH scavenging assay. These compounds have ability to reduce free radicals and have in $\mathrm{IC}_{50}$ value of $46.61 \mu \mathrm{g} / \mathrm{mL}-$ $88.64 \mu \mathrm{g} / \mathrm{mL}$ (Table 3). The ethyl acetat fraction has the strongest antioxidant activity compare to ethanol extract and ethanol fraction.

\section{Cytotoxic Activity}

In terms of the value, the ethanol extract, ethanol fraction, ethyl acetat fraction and n-hexane fraction obtained $233.43 \mu \mathrm{g} / \mathrm{mL}, 700.75 \mu \mathrm{g} /$ $\mathrm{mL}, 45.57 \mu \mathrm{g} / \mathrm{mL}$, and $534.30 \mu \mathrm{g} / \mathrm{mL}$, respectively. According to Weerapreeyatkul, et al. (2012), the ethyl acetate fraction of parijoto fruit had activity as an anticancer agent in the strong cytotoxic category with an average in the range of $10-100 \mu \mathrm{g} / \mathrm{mL}$, ethanol extract had moderate cytotoxicity with an average in the range $100-500 \mu \mathrm{g} / \mathrm{mL}$, and ethanol fraction and $n$-hexane fraction were categorized as non-toxic compared to the positive control. Meanwhile, doxorubicin was categorized as very strong cytotoxicity with a value $<10 \mu \mathrm{g} / \mathrm{mL}$. Compare with the Parijoto extract and other fractions, the ethyl acetate fraction had the highest cytotoxic activity against HeLa cancer cells with a value of $45.57 \mu \mathrm{g} /$ $\mathrm{mL}$.

Table 2. Phytochemical screening.

\begin{tabular}{lcccc}
\hline $\begin{array}{c}\text { Secondary } \\
\text { metabolites }\end{array}$ & $\begin{array}{c}\text { Ethanolic } \\
\text { Extract }\end{array}$ & $\begin{array}{c}\text { Ethyl Acetate } \\
\text { fraction }\end{array}$ & $\begin{array}{c}\text { Ethanolic } \\
\text { Fraction }\end{array}$ & $\begin{array}{c}\text { n-hexane } \\
\text { fraction }\end{array}$ \\
\hline Flavonoid & + & + & + & + \\
Tanin & + & + & + & + \\
Alkaloid & - & - & - & - \\
\hline
\end{tabular}


Table 3. $\mathrm{IC}_{50}$ of Antioxidants.

\begin{tabular}{|c|c|c|c|}
\hline Tested Compounds & Linear Regression Equations & $\mathrm{IC}_{50}(\mu \mathrm{g} / \mathrm{mL})$ & Statement \\
\hline Vitamin C & $\begin{array}{c}y=0.8795 x+40.932 \\
R^{2}=0.9931\end{array}$ & 10.31 & Very Strong \\
\hline Ethanol Extract & $\begin{array}{c}y=|.576| x-7 \mid .974 \\
R^{2}=0.9983\end{array}$ & 77.39 & Strong \\
\hline Ethanol Fraction & $\begin{array}{c}y=1.3688 x-71.333 \\
R^{2}=0.9958\end{array}$ & 88.64 & Strong \\
\hline Ethyl Acetate Fraction & $\begin{array}{c}y=2.1739 x-51.068 \\
R^{2}=0.9613\end{array}$ & 46.61 & Very Strong \\
\hline
\end{tabular}

Changes in cell morphology were characterized by changes in the shape of cells, which were initially identical round, oval, and taper that later became irregular after the treatment.

\section{DISCUSSION}

Parijoto fruits have a considerable potential to be developed into chemo-preventive agents. The results of this study showed that Parijoto fruit contained flavonoids and tannins (Table 2). Previous study also revealed that Parijoto fruit contained flavonoids, saponins, kardenolin and tannins
(Octaviani, 2016; Tusanti, et al., 2014; Vifta and Advistasari, 2018). The antioxidant activity and cytotoxic effect was alike due to flavonoids and tannins in Parijoto fruit. There were large amounts of flavonoid compounds that could bind free radicals; thus, many flavonoids from extracts and fractions of Parijoto fruit could contribute hydrogen to DPPH as free radicals (Amić, et al., 2003; Es-Safi, et al., 2007).

The ethyl acetate fraction in parijoto fruit was proven to have a toxic cytotoxic activity with an $\mathrm{IC}_{50}$ value of $45.57 \mu \mathrm{g} / \mathrm{mL}$ (Table 4). Compounds with an $\mathrm{IC}_{50}$ value of $10-100 \mu \mathrm{g} / \mathrm{mL}$ were strong

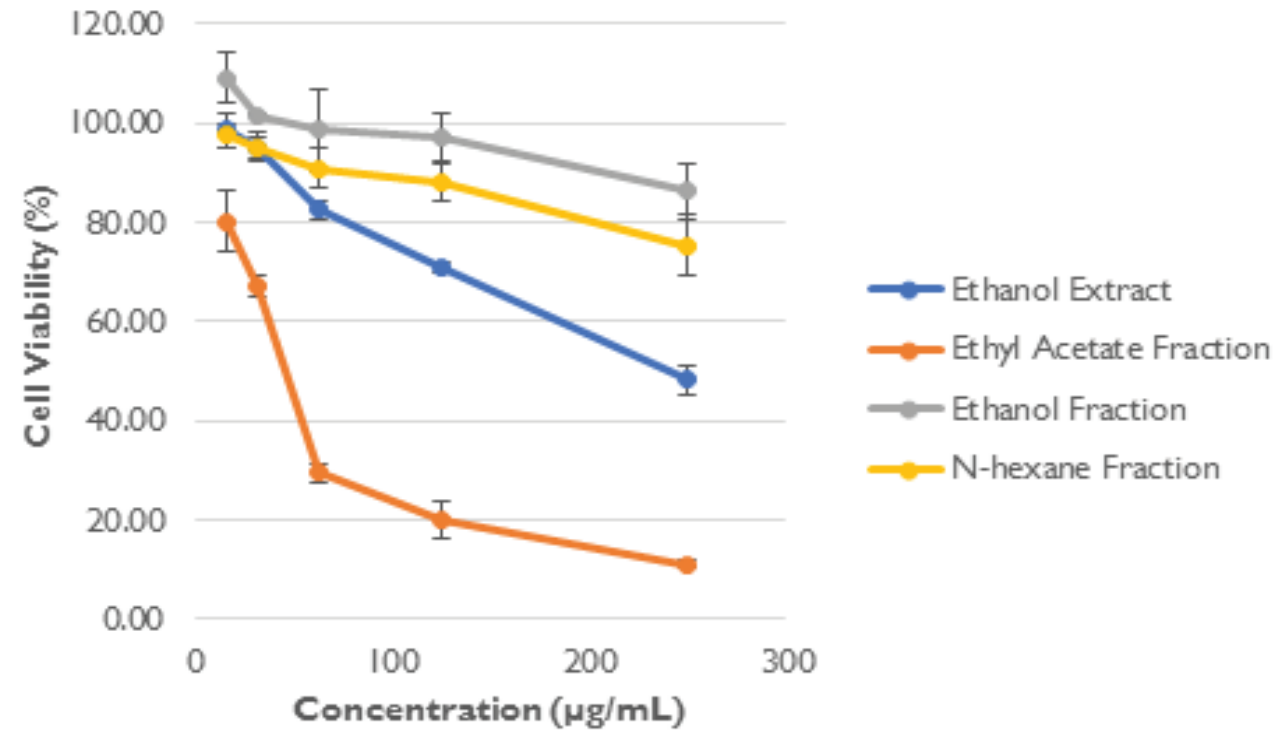

Figure 2. Percentage of HeLa living cell after sample treatment. 
Table 4. Results of cytotoxic activity $\left(\mathrm{IC}_{50}\right)$.

\begin{tabular}{|c|c|c|c|}
\hline Tested Compounds & Linear Regression Equations & $I C_{50}(\mu \mathrm{g} / \mathrm{mL})$ & Statement \\
\hline Doxorubicin & $y=-24.304 x+91.108$ & \multirow[b]{2}{*}{1.69} & Very strong cytotoxicity \\
\hline & $R^{2}=0.9839$ & & \\
\hline Ethyl Acetate Faction & $y=-61.613 x+152.2$ & \multirow[b]{2}{*}{45.57} & Strong cytotoxicity \\
\hline & $\mathrm{R}^{2}=0.9324$ & & \\
\hline Ethanol Extract & $y=-0.2126 x+99.629$ & \multirow{2}{*}{233.43} & Moderate cytotoxicity \\
\hline & $\mathrm{R}^{2}=0.9803$ & & \\
\hline Ethanol Fraction & $y=-0.0798 x+105.92$ & 700.75 & Less cytotoxicity \\
\hline $\mathrm{N}$-Hexane fraction & $\begin{array}{c}R^{2}=0.9214 \\
y=-0.0899 x+98.034 \\
R^{2}=0.9859\end{array}$ & 534.30 & Less cytotoxicity \\
\hline
\end{tabular}

cytotoxic activity (Weerapreeyakul, et al., 2012). The characteristic of HeLa cells is the degradation of p53 due to the binding of the HPV E6 protein complex to cellular factor E6AP which causes proteasome-mediated degradation (Buitrago-Pérez, et al., 2009). Several study showed that ethyl acetate fraction from plants was able induced p53 wild type protein. This may cause the ethyl acetate fraction has strong cytotoxic activity against HeLa cell (Husnaa, et al., 2017). It also corresponded to the ethyl acetate fraction's antioxidant activity with an $\mathrm{IC}_{50}$ value of $46.61 \mu \mathrm{g} / \mathrm{mL}$ (Table 3). These $\mathrm{IC}_{50}$ values were included in the group of compounds with robust antioxidant activity as they had an $\mathrm{IC}_{50}$ value of $<50 \mu \mathrm{g} / \mathrm{mL}$ (Mardawati, et al., 2008). Based on the results of this study, the relationship between antioxidant effects and cytotoxic effects was directly proportional, where the more substantial the antioxidant activity is, the greater the cytotoxic effect will be. The ethanol extract of Parijoto fruit was proved to have a cytotoxic effect on T47D cells (Tusanti, et al., 2014), and hydrolyzable tannin had the strongest cytotoxic effect on human leukemia cells (Yang, et al., 2000).

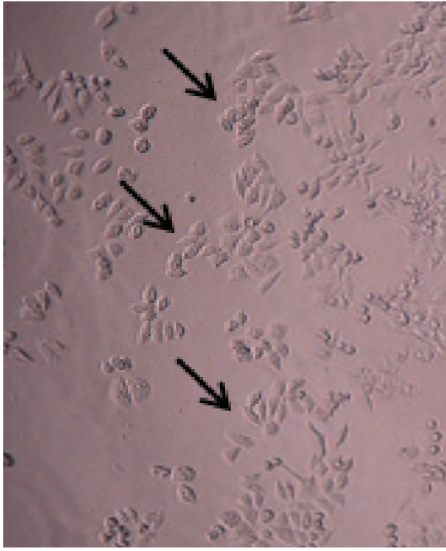

A

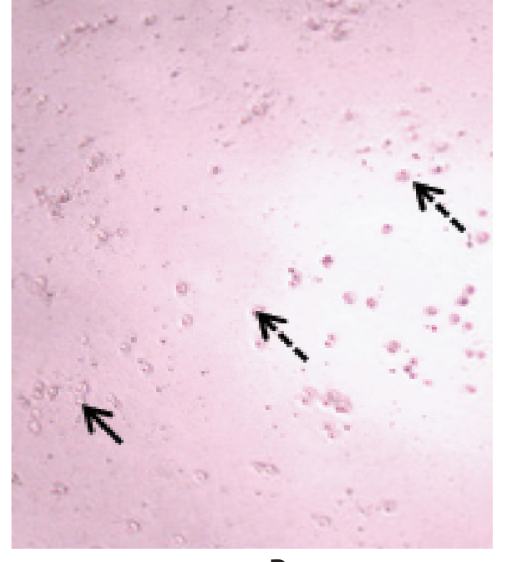

B

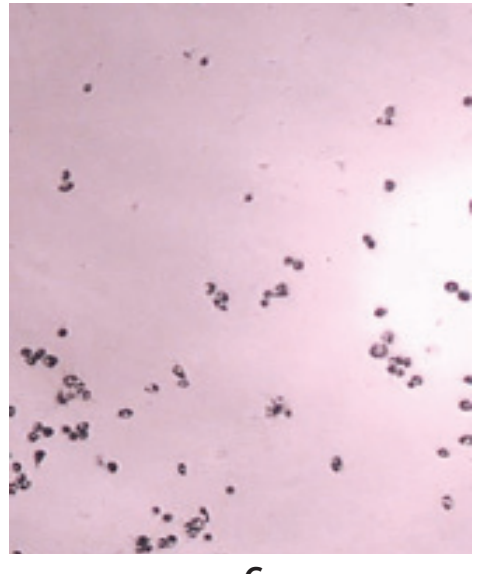

C

Figure 3. HeLa cells' morphology with ethyl acetate fraction treatment. (A) Before being treated with a sample (B) After being treated with a sample (C) After treatment as well as incubation and addition of MTT reagent. Living cells $(\longrightarrow)$ Dead cells $(-->)$. 


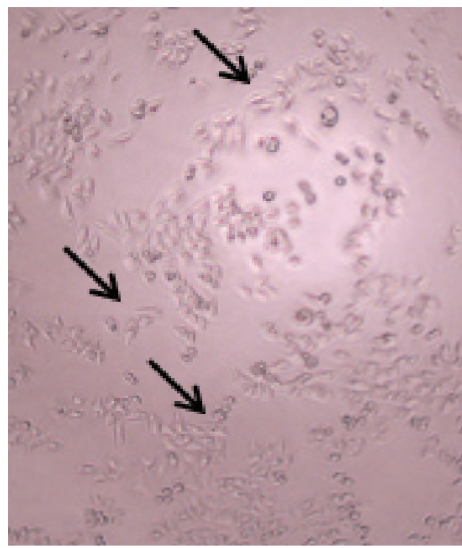

A

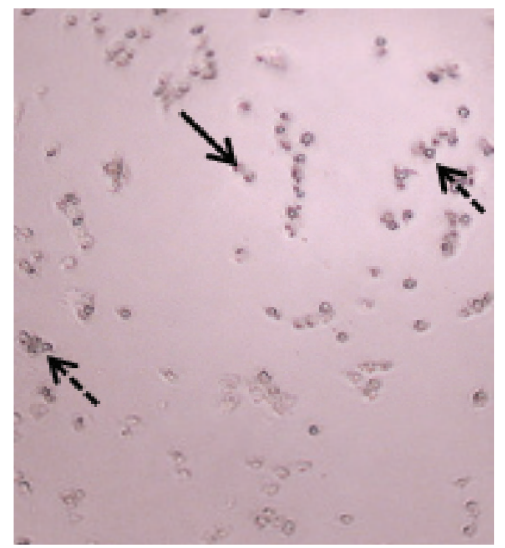

B

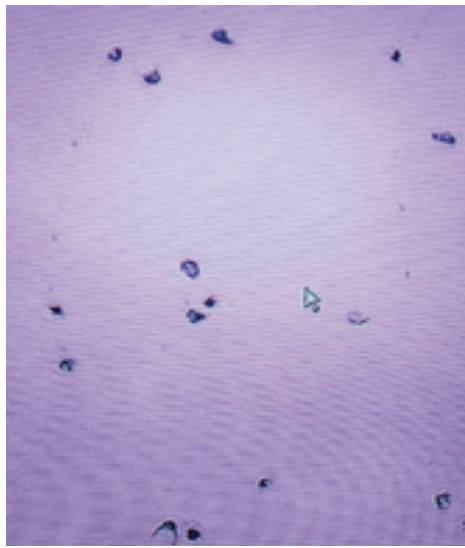

C

Figure 4. HeLa cells' morphology with doxorubicin treatment. (A) Before being treated with a control sample (B) After being treated with a control sample (C) After treatment as well as incubation and addition of MTT reagent. Living cells $(\longrightarrow)$ Dead cells $(-->)$.

The antioxidant activity and the resulting cytotoxic effect may be due to the flavonoid and tannin content in Parijoto fruit. Many flavonoids and tannins compounds were dissolved in a semipolar solvent such as ethyl acetate. Components of phenolic compounds such as flavonoids, tannins, and phenols are examples of several phenolic compounds that have antioxidant activity, and it can ward off free radicals that become one of the causes of cancer (Meenakshi, et al., 2011). The cytotoxic activity indicates that flavonoid compounds can increase the inhibitory effect on cancer cells so that the ethanol extract and ethyl acetate fraction of Parijoto fruit has the potential to be developed as a chemopreventive agent in the treatment of cervical cancer. The growth of cancer cells can be inhibited in the presence of antioxidants as they have similar inhibition mechanisms at the cellular level. The flavonoid action, which has anti-cancer properties, includes inhibition of carcinogenesis' inactivation, cell cycle inhibition, angiogenesis inhibition, cell proliferation, and apoptotic mechanisms (Abotaleb, et al., 2018; Chahar, et al., 2011). The cytotoxic activity mechanism of tannin induces apoptosis in HL-60 cells and HS-683 cells by increasing ROS production, activation of pro-capcase 3 , and capcase 9 (Yang, et al., 2000; Zhang, et al., 2018).

\section{CONCLUSION}

The ethanol extract and parijoto fruit fraction contained secondary phytochemical metabolites of flavonoids and tannins. The ethyl acetate fraction of parijoto was a robust antioxidant activity with an $\mathrm{IC}_{50}$ value of $46.61 \mu \mathrm{g} / \mathrm{mL}$, and cytotoxic activity was toxic to HeLa cervical cancer cells with an $\mathrm{IC}_{50}$ value of $45.57 \mu \mathrm{g} / \mathrm{mL}$. Based on these results, the ethyl acetate fraction of Parijoto fruit had the potency to be explored further to elucidate their cytotoxicity mechanism in HeLa cells.

\section{ACKNOWLEDGMENT}

The author would like to thank Culture Cell Laboratory UMY for providing the cell collection and support; thus, this research was well conducted. This research was funded by Hibah Kemitraan LP3M UMY grant 2019 from Universitas Muhammadiyah Yogyakarta.

\section{REFERENCES}

Abotaleb, M., Samuel, S., Varghese, E., Varghese, S., Kubatka, P., Liskova, A. and Büsselberg, D., 2018, Flavonoids in Cancer and Apoptosis, Can- 
Indonesian Journal of Cancer Chemoprevention, June 2021 ISSN: 2088-0197

e-ISSN: $2355-8989$

cers., 11, 28.

Amić, D., Davidović-Amić, D., Bešlo, D. and Trinajstić, N., 2003, Structure-radical scavenging activity relationships of flavonoids, Croat. Chem. Acta., 76(1), 55-61.

Ayoola, G., Coker, H., Adesegun, S., Adepoju-Bello, A., Obaweya, K., Ezennia, E. and Atangbayila, T., 2008, Phytochemical Screening and Antioxidant Activities of Some Selected Medicinal Plants Used for Malaria Therapy in Southwestern Nigeria, Trop. J. Pharm. Res., 7(3), 1019-1024.

Buitrago-Pérez, Á., Garaulet, G., Vázquez-Carballo, A., Paramio, J.M. and García-Escudero, R., 2009, Molecular Signature of HPV-Induced Carcinogenesis: pRb, p53 and Gene Expression Profiling, Current Genomics., 10, 26-34.

Chahar, M., Sharma, N., Dobhal, M. and Joshi, Y., 2011, Flavonoids: A versatile source of anticancer drugs, Pharmacogn., 5(9), 1-12.

Es-Safi, N.-E., Ghidouche, S. and Ducrot, P., 2007, Flavonoids: Hemisynthesis, Reactivity, Characterization and Free Radical Scavenging Activity, Molecules., 12, 2228-2258.

Harborne, T.B., 1987, Metode Fitokimia: Penuntun Cara Moderen Menganalisis Tumbuhan. ITB Bandung.

Huang, C.-Y., Ju, D.-T., Chang, C.-F., Muralidhar Reddy, P. and Velmurugan, B.K., 2017. A review on the effects of current chemotherapy drugs and natural agents in treating non-small cell lung cancer, BioMedicine., 7(4), 12-23.

Husnaa, U., Laksmiani, N.P.L., Susidarti, R.A. and Meiyanto, E., 2017, Ethyl Acetate Fraction of Caesalpinia sappan L. Enhances Cisplatin's Cytotoxicity on HeLa Cells via G1 and S Arrest through p53 Expression, Indones, J. Cancer Chemoprevention., 8(2), 51-56.

Jork, H. (Ed.), 1990, Thin-layer chromatography: reagents and detection methods. Vol. 1 a: Physical and chemical detection methods Fundamentals, reagents I. VCH, Weinheim.

Kaulika, N. and Febriansah, R., 2019, Chemopreventive Activity of Roselle's Hexane Fraction

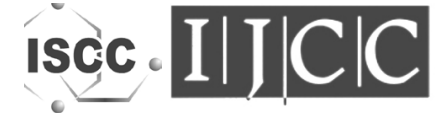

against Breast Cancer by In-Vitro and In-Silico Study, Proceedings, Yogyakarta,: The Third International Conference on Sustainable Innovation 2019 - Health Science and Nursing (IcoSIHSN 2019), Atlantis Press: Advances in Health Sciences Research. 15, 66-71.

Krueger, R.J., 2005, Drugs of Natural Origin, J. Nat. Prod., 68, 629-629.

Man, S., Gao, W., Zhang, Y., Huang, L. and Liu, C., 2010, Chemical study and medical application of saponins as anti-cancer agents, Fitoterapia, 81, 703-714.

Manuaba, T.W., 2010, Panduan penatalaksanaan kanker solid PERABOI 2010, Sagung Seto: Jakarta.

Mardawati, E., Filianty, F. and Marta, H., 2008, Kajian Aktivitas Antioksidan Ekstrak Kulit Manggis (Garcinia mangostana L.) Dalam Rangka Pemanfaatan Limbah Kulit Manggis di Kecamatan Puspahiang Kabupaten Tasikmalaya, TEKNOTAN: Jurnal Industri Teknologi Pertanian, 2.

Meenakshi, S., Umayaparvathi, S., Arumugam, M. and Balasubramanian, T., 2011, In vitro antioxidant properties and FTIR analysis of two seaweeds of Gulf of Mannar, Asian Pac. J. Trop. Biomed., 1, S66-S70.

Ministry of Health RI, 2006, Inventaris Tanaman Obat Indonesia (V), Balai Penelitian Tanaman Obat, Jakarta.

Octaviani, I., 2016, Aktivitas Antibakteri Ekstrak Daun Parijoto (Medinilla speciosa) Terhadap Escherichia coli dan Staphylococcus aureus, Thesis, Universitas Atma Jaya Yogyakarta, Yogyakarta.

Oun, R., Moussa, Y.E. and Wheate, N.J., 2018, Correction: The side effects of platinum-based chemotherapy drugs: a review for chemists, Dalton Trans., 47, 7848-7848.

Phang, C.-W., Malek, S.N.A., Ibrahim, H., 2013, Antioxidant potential, cytotoxic activity and total phenolic content of Alpinia pahangensis rhizomes, BMC Complement. Altern. Med., 13, 243.

Ren, W., Qiao, Z., Wang, H., Zhu, L. and Zhang, L., 
2003, Flavonoids: Promising anticancer agents, Med. Res. Rev., 23, 519-534.

Riss, T.L., Moravec, R.A., Niles, A.L., Duellman, S., Benink, H.A., Worzella, T.J. and Minor, L., 2013, Cell Viability Assays, in: The Assay Guidance Manual. Bethesda (MD): Eli Lilly \& Company and the National Center for Advancing Translational Sciences, pp. 1-25.

Tiwari, P., Kumar, B., Kaur, M., Kaur, G. and Kaur, H., 2011, Phytochemical screening and Extraction: A Review, Internationale Pharmaceutica Sciencia, 1, 98-106.

Tusanti, I., Johan, A. and Kisdjamiatun, R., 2014, Sitotoksisitas in vitro ekstrak etanolik buah parijoto (Medinilla speciosa, reinw.ex bl.) terhadap sel kanker payudara T47D, J. Gizi Indones. Indones. J. Nutr., 2, 53-58.

Vifta, R.L. and Advistasari, Y.D., 2018, Skrining Fitokimia, Karakterisasi, dan Penentuan Kadar Flavonoid Total Ekstrak dan Fraksi-Fraksi Buah Parijoto (Medinilla speciosa B.), Proceeding,
Semarang: Seminar Nasional , pp: 8-13.

Weerapreeyakul, N., Nonpunya, A., Barusrux, S., Thitimetharoch, T. and Sripanidkulchai, B., 2012, Evaluation of the anticancer potential of six herbs against a hepatoma cell line, Chin. Med., 7, 1-7.

World Health Organization, 2018, Cancer., Website, https://www.who.int/news-room/fact-sheets/ detail/cancer, accesed on May 24, 2019.

Yang, L.-L., Lee, C.-Y. and Yen, K.-Y., 2000, Induction of apoptosis by hydrolyzable tannins from Eugenia jambos L. on human leukemia cells, Cancer Lett., 157, 65-75.

Yang, X.-W., Dai, Z., Wang, B., Liu, Y.-P., Zhao, X.D. and Luo, X.-D., 2018, Antitumor Triterpenoid Saponin from the Fruits of Avicennia marina, Nat. Prod. Bioprospecting., 8, 347-353.

Zhang, J., Chen, D., Han, D., Cheng, Y., Dai, C., Wu, X., Che, F. and Heng, X., 2018, Tannic acid mediated induction of apoptosis in human glioma Hs 683 cells, Oncol. Lett., 15, 6845-6850. 